\title{
The Definition of Firm Boundaries and Its Impact on Sustainability
}

\author{
Luis Armando Luján Salazar ${ }^{1} \&$ Gonzalo Maldonado Guzmán ${ }^{1}$ \\ ${ }^{1}$ School of Business and Economics, Universidad Autónoma de Aguascalientes, Ags., Mexico \\ Correspondence: Luis Armando Lujan Salazar, School of Business and Economics, Universidad Autónoma de \\ Aguascalientes, Ags, Mexico. E-mail: luislujan@hotmail.com
}

Received: April 10, $2017 \quad$ Accepted: May 5, $2017 \quad$ Online Published: May 29, 2017
doi:10.5539/jms.v7n2p126

\begin{abstract}
The way in which the boundaries of a firm are defined also determines its responsibilities. Besides the firm's goals of profitability and survival, there are implications beyond its physical boundaries, such as sustainability. There are several definitions of the boundaries of a firm, each one with its own implications. Considering external resources related to the firm may allow decision makers to take responsibility for what takes place beyond its frontiers. Because firms are not isolated, sustainability goes beyond the boundaries of the firm and requires incorporating external factors.

The relation of a firm with its external factors can be established in several dimensions; one of them is considering the relation of the firm with its environment. In this study, we reviewed literature on firm boundaries and found out that the boundaries, limits, and responsibilities of firms are not sharply defined. An interesting point is that the boundaries of the firm can be expanded to account for external resources and the impact of the firm's activities, so that the firm may take steps to reduce its green footprint and contribute to sustainability from the perspective of the triple bottom line, which includes economic, social, and environmental aspects.
\end{abstract}

Keywords: sustainability, firm boundaries, economic incentives, sustainable business model

\section{Introduction}

Propelled by the Industrial Revolution and the emergence of management in the late eighteenth century, firms began to flourish, as well as literature about firms and their implications. One of the early streams of literature came from economics, in the form of classical theory. In an update of economic theory, Alchian \& Demsetz (1972) and Jensen \& Meckling (1976) presented the concept of neoclassical theory, which acknowledges firms by their productive function. The main assumption in this view is that organizing production within the firm is more efficient than organizing production through independent parties. This theory regards the firm as a black box, without links with the external environment (Jensen \& Meckling, 1976). Neoclassical economics has focused on explaining patterns such as how prices are determined rather than how they change over time. Another economic view is the endogenous growth theory, which differs from the Neoclassical view in its assumption that technology is endogenous to the firm and that the growth process is based on the lack of decreasing returns on capital (Romer, 1986, 1994).

From an economic point of view, the firm is a production function. In the classical view, theory ignores the impact of the firm beyond its boundaries, and cannot explain under what circumstances the firm is a superior form of organization, neither its impact on the environment and the level of sustainability. Economic arguments disregard the impact of a firm's activities on natural resources. Neoclassical view and endogenous growth are focused on technology, capital, and labor.

Coase (1937) explains a firm's reason for existing in terms of transaction costs: "The main reason why it is profitable to establish a firm would seem to be that there is a cost of using the price mechanism" (p. 390). If an organization can produce at lower costs than market standards, then the firm might exist by reducing the cost of transactions. Criticism on this approach includes, for instance, the statement that specific costs are often ad hoc adducedto explain economic organizations (Alston \& Gillespie, 1989).

Concerning the discussion around setting the firm's boundaries: "These new boundaries are more psychological than organizational. They aren't drawn on a company's organizational chart but in the minds of its managers and employees." (Hirschhorn \& Gilmore, 1992, p. 104). Beyond the market-firm dichotomy, in opening the black box of the economic stream, new theories have complemented and provided new insights, among which are 
recent ideas about the limits or boundaries of the firm, for instance: "unit of accrual, governance structure to resolve agency problems through residual claims, and a repository of coordinating capabilities and social identity" (Kogut, 2000, p. 406). These ideas have their implications. First, we need to realize that there is no clear delimitation on the concept of firm and its boundaries or processes.

"A firm is by no means an unambiguous clear-cut entity. It is not a physically observable object separable from other objects" (Penrose, 1959, p. 10). In view of this lack of a clear-cut definition of the firm, we ought to consider criteria for setting boundaries. One problem in delimiting such boundaries is that authors usually take a one-dimensional approach, such as control-, ownership-, cooperation-, or cost of transactions-related limits, and sometimes a mixed approach with those elements; according to Bain (1968) "the scope of a single enterprise is conveniently viewed as the total of assets and operations which, because of common ownership, are controlled by a single management" (p. 5, my italics). The chain of control is one of the most common delimiters for the boundaries of a firm. In the present paper, we argue that external resources and their interactions should be taken into account by expanding the boundaries of the firm. But before dealing with external resources, we will review firm boundaries and analyze how external as well as internal resources play a role in the firm's performance beyond the constraints of control and ownership.

\subsection{The Boundary of the Firm as a Chain of Control}

Penrose (1959), in line with Chester Barnard's concept, set the boundaries of the firm as an area of authoritative communication. For Penrose, authoritative communication can consist in the transmission of instructions or information through a hierarchy of officials. According to this view, the boundaries of the firm are set by the chain of control. However, effective coordination and control are some theoretical drivers among several possibilities for defining a firm's boundaries, since each department is loosely coupled with the rest of the firm. If an agent might place their interests before the company's goals, as agent theory suggests, similar self-interest could be expected from a department; as Weick (1976) explains, we might expect each department to have its own goals, which can sometimes be opposed to the rest of the department's goals. Therefore, control fades as the goal of the department exercising power differs from the goals of other departments.

Sometimes, control can be difficult to exercise. Carrillo (1993) claims that the cost of coordination can be reduced by dividing a large company into smaller units: "Each unit, by working for its interest, would act in the benefit of the group, without imposing the burden of a controlling, reward-awarding bureaucracy" (p. 17). Ashkenas et al. (1995) are concerned with the possibility of competition among different departments, part of this behavior is due to the different boundaries and goals across departments. They propose to reduce these barriers by appointing cross-functional teams to organize activities around processes. According with Shrivastava (1995), firms are groups of individuals looking to satisfy their own agendasbetter than meeting the company's goal and requirements.

Space and time can play an important role when we try to partition a firm into departments-let us consider near decomposability systems. Near decomposability systems are those where short-run behavior is independent from the rest of the system, but in the long run it is not. The following is a classic example: "in formal organizations, where the formal authority relation connects each member of the organization with one immediate superior, departmental boundaries play very much the same role [as in near decomposability systems]." (Simon, 1962, p. 201). Therefore, what Penrose saw as a firm could be regarded, according to her definition, as a collection of firms. In strategy literature, the concept of control can be found in relation with a firm's resources:

"A Firm's resources include all assets, capabilities, organizational processes, firm attributes, information, knowledge, etc. controlled by a firm that enable the firm to conceive of and implement strategies that improve its efficiency and effectiveness [...] in the language of traditional strategic analysis, firm resources are strengths that firms can conceive of and implement their strategies" (Barney, 1991, p. 101, my italics).

As previously discussed, control is a matter of degree. It ranges from tight supervision to loose supervision styles: in comparison with a military unit, the relatively flat authority and control structure found in many voluntary associations contrasts with multilayer hierarchies (Scott, 1992, p. 12). Hierarchies are regarded as necessary control mechanisms as much as criticized for their lack of flexibility. Control can also be exercised from outside the firm. At a different level of analysis, and to some extent, consumers and suppliers have some power over the firm (Porter, 1980). Control is a way to relate with people or resources in a dyadic relationship. These people and resources may be part of the firm itself, but may also belong to the external environment. Some departments might have more interactions with either the supplier or the customer than they have with organizations in their own firm. 


\subsection{The Firm as a Collection of Resources under a Common Ownership}

Externalities can be internalized through ownership. According with Demsetz (1967) the main function of property rights is to guide incentives to achieve an internalization of externalities. Sometimes, ownership is cited as a boundary of the firm; however, ownership is neither sufficient nor a necessary condition:

"[T]he concept of the firm [...] does not depend on the ramifications of stock ownership or the mere existence of the power to control, although extensive stock ownership may, and probably should, be one important consideration in any attempt to apply it. On the other hand, long-term contracts, leases, and patent license agreements may give an equally effective control". Penrose (1959, p. 21).

Resource-based view (RBV) is a recent stream of literature that considers the firm's resources and capabilities (Newbert, 2007). In RBV, resources are seen as valuable, rare, imperfectly imitable, and without equivalent substitutes (the VRIN attributes), and because RBV is mainly focused on the firm's internal resources, it is possible to have some doubts whether a firm's interaction with its external resources is actually noticed. In clarifying definitions and explaining the role of external variables, Peteraf \& Barney (2003) argued: "In our view, RBT [the next step of RBV] holds constant the contributions of other levels of analysis toward understanding profitability. It employs the ceteris paribus assumption regarding these other effects." (p. 319).

There is no evidence that becoming "green" will generate a "potential self-benefit" (Holmberg \& Robert, 2000, p. 297). One reason for this could be that some firms benefit of not taking care of their externalities; while a firm can be facing a rather rigid legislation, another similar firm can make an extra profit derived from a relaxed legislation. Waste did not exist before human activity, which was propelled by the industrial revolution and factories. Expanding factory and firm boundaries and forcing both to take responsibility of their externalities might balance and improve our conditions, or in other words, lead to higher sustainability. Although free riding may provide short time incentives to firms that to some extent fail to account for their impact, for instance short-term savings, in the long run, such failure may impair the firm's ability to improve or become a better competitor. Porter (1980) explains how a difficult environment can lead to innovation and competitiveness; for example, having a relaxed legislation might provide an additional advantage in the short run, but the same circumstance can prevent the firm from acting and improving its performance. Not all legislations or environments are homogeneous; some firms might take advantage of those, whereas some others, framed by stronger legislation and concern for external factors, will be willing to improve their performance and their relationship with their environment. After all, not only firms have boundaries: states, regions, and countries have their own delimitations as well.

Firms do have an impact on the environment, related both with their inputs and their products and processes. In part, because of the resources and the environment external to the firm, firms go through a selection process which not all of them survive. This might foster the creation of certain types of firms in certain regions by way of clusters. Therefore, the area selected for a firm's operations can be defined by the environment or by legislation. Selection can be used to choose what kind of firm or technology may be allowed in the region; for example, a highly controversial oil and gas technique, fracking, is not allowed in some states of the USA.

Maximizing value for the stakeholders is just one level of analysis, and only one of the firm's goals. This level of analysis is employed from a mostly economic point of view; a multilevel theory including the levels of survival and ethics could help to improve our understanding of the behavior of the firm. An effort on that direction is the triple bottom line (TBL), where the economic, social, and environmental aspects are included (Goel, 2010). In the TBL, the three bottom lines are profit, people, and planet (Elkington, 1997). This paper is concerned with opening the boundaries of the firm to incorporate its environment, which is covered by the TBL main goals.

MacMillan \& Farmer (1979) explain that, in the late nineteenth century, each department within the same factory was operated by different subcontractors. In their belief, a business organizationcan be compared with a confederation of 'firms' in a vertical relation. There are certain authors that employ both drivers of control and ownership. According to Bain (1968), separate enterprises are different complexes of assets and operations under different ownerships and separate and independent control managements. After all, there are other alternatives besides ownership. For example, leasing or subcontracting is always an option. In this paper, ownership and control are enclosed in a wider variable termed relation. The relation of a firm with its environment presents new challenges.

\section{Discussion}

Limits or boundaries can be established by people, departments, or firms, and each party might establish their own goals and agendas, which might not necessarily be in the best interest of all the involved agents. Beyond the limits of the firm, there are interrelations that create certain specific (idiosyncratic) configurations that can be 
expressed as a value chain (Porter, 1985), such as cluster, industrial sector, and even nation (Porter, 1991). As a final argument regarding interactions, inTeece's (1993) summary on Chandler's work, the implicit thesis is that firms and markets evolve together and to some extent determine their outcomes. This calls for the recognition of the interaction of firms, the environment, and the markets. Shrivastava (1995) explains that the firm's vision defines the relationship between the firm and its environment, and ultimately its sustainability.

Interaction between agents, firms, and clusters is also acknowledged outside strategy theory. Network theory stresses the importance of taking into account the links with other firms and the capabilities developed as a result of those relationships (Gulati, 2000; Takesishi, 2001), and also and the importance of taking into account that the firm is "embedded in structures of social relations" (Granovetter, 1985, p. 481). Another stream of research makes a similar claim; Nonaka \& Nishiguch (2001) state that knowledge can be observed on two levels, the individual and the social, which brings the opportunity and challenge of observing the event from different levels of analysis. As can be seen, a firm may have several knowledge agents, but the creation of knowledge in an exchange could exceed the firm's boundaries. Checkland (2000) wrote on systems theory: "we tended only to make models whose (systems) boundaries correspond to real-world organization boundaries" (Checkland, 2000, p. A21); the author adds that this is a self-imposed limitation and that those purposeful activities can be institutionalized by means of a structure. Unfortunately, some firm theory and economic researchers, from an atomistic perspective, have unnecessarily constrained the impact of a firm's resources and capabilities to its boundaries (McEvily, Zaheer, 1999; Gulati, 2000; Takesishi, 2001).

\subsection{Sustainability and Firm Boundaries}

Sustainability has been gaining attention in management literature since the concept of ecologically sustainable development (ESD) was described in 1987 in the Brundtland Commission Report; in the same year, the World Commission on Environment and Development (WCED) took place, followed by the Earth Summit in Rio de Janeiro, in 1992. Firms (organizations) are the main source of economic development, they can provide ecological solutions, and management literature highlights related areas of opportunity (Shrivastava, 1995). Reinhardt (1998) goes beyond the question of whether green pays off or not, and he proposes instead a different question: "Under what circumstances do particular kinds of environmental investment deliver returns to shareholders?" (p. 35).

Opening the boundaries of the firm is part of the solution, but this initiative should necessarily be articulated in several of the firm's goals and ought to include several levels of analysis: individual, group, and department behavior, as well as firm and societal levels. Given that a firm is more than an entity devoted exclusively to produce profit, it should be concerned with several goals. Profit has been the traditional subject matter in economics, but considering environment sustainability becomes an important focus area (Reinhardt, 1998). In order to achieve a sustainable environment, it is necessary to look beyond the firm's physical space or annual profits. A sustainable competitive advantage should involve a sustainable relation with the environment.

An emergent body of literature studies sustainability in association with firm boundaries, which pursues a more sustainable society; some examples are presented next. Vertical boundaries are expanding, both mentally and physically: Interfunctional teams can replace vertical hierarchies, other options are networks linking traditional functions (Hirschhorn \& Gilmore, 1992). One area of special interest for vertical boundary structures is the chain of purchasing and supply management (PSM) where the relation with the supplier entails selection, evaluation, and development (Schiele, 2007).

The make-buy decision is particularly critical for firms pursuing a sustainability-focused strategy because firms requires that every aspect of the supply chain should have a similar scope and goals (Özcan \& Reeves, 2013). From the economic point of view, vertical boundaries have been analyzed from two main perspectives or traditions: 1) organizational economics, parting from seminal works from Coase (1937) and Williamson (1975); and 2) industrial economics, where vertical integration is a response to contractual challenges. Industrial economics is also focused on market structure. An emergent tradition is concerned with developing a natural capitalism, which recognizes the impact of waste and the non-renewability of some resources (Hawken, Lovins, \& Lovins, 1999).

Circular economy goes beyond the intention of reducing the footprint and not harming the environment: circular economy is restorative and regenerative by intention and design. It shifts the focus from a "take, make and waste" production to a "reduce, reuse and recycle" mentality; the conception and implementation of production under this concept would benefit from the openness of firms' boundaries. One important aspect of the implementation of a circular economy are circular products. Circular products can be facilitated and implemented via four elements: materials and product design, new business models, global reverse networks, and enabling conditions, 
proposing a new business model and relevant networks can be an integral part of the expansion of the firm's limits, and part of its responsibilities.

\subsection{Substitutes and Literature Complements}

Sustainability can be possibly achieved only byincreasing the integration between the different levels of analysis and theoretical approaches, their theoretical substitutes, as well asany complements than could contribute towarda common position. Expanding the boundaries of the firm is one possible step toward higher sustainability, but there are substitutes and complementary policies that can be part of an integral solution, such as governmental policies, taxes, extended responsibility and ethics, among others, which might as well make the firm, its components and personnel to ponder the externalities of the firm.

Another stream of economic literature relates firm boundaries, free riding, and firm externalities. The free rider problem states that a firm can take a profitable advantage by disregarding the damage to its environment. The issue arises from the fact that an individual or firm may be able to obtain the benefits of a good without contributing to its cost (Hardin, 1968; Olson, 1968). Under the view of firm boundaries, free riding may have taken place because the external environment is not part of the firm's definition, and thus what happens outside it is not part of its range of ownership or control. This is where supply chain management can help to internalize the actions that affect the firm's environment.

A firm can incorporate sustainability principles within business strategies by redefining their boundaries and degree of commitment through support for sustainability agreements, which include external and internal sustainable development and allocating resources to address sustainability issues beyond the immediate control of the company (Labuschagne et al., 2005, p. 376).

Nevertheless, we argue that a big piece of the puzzle is missing: while economics has a market to signal, guide, and direct relationships (the "invisible hand"), sustainability lacks such mechanism. Various entities try to participate and provide some guidance, but without an economic incentive, sustainability can always be viewed as someone else's problem. How to determine and assign responsibilities and how to enforce a commitment toward a sustainable environment? This case is especially difficult in the case of river pollution, since several firms dispose of their waste products in the same aquifers. Moreover, not only does current economic activity generate increased pollution, there is also accumulated pollution from the past. Some firms and industries might have an environmental passive, and some polluting industries do not even exist today. For example, how to solve this problem in the oil and gas industry if the industry can hardly survive in a low-price market and its cash flow is redirected to more pressing issues via royalties and taxes.

A necessary complement is a regulation - a law-to foster and guide the relationships with other agents, including the environment. The invisible hand is about efficient location, but not about sustainability, hence an external agent is needed to complete and regulate such interchanges and conditions (Sjåfjell \& Taylor, 2015). There is an emergent body of literature that complements the mainstream view of maximizing utilities by considering society's purpose at the same time (Sjåfjell, 2016).

Sustainability can be a complex and challenging problem. Despite several streams of literature and scientific forums address care for the environment - where a complementary view is of utmost importance-, we might also pursue co-responsibility and an integrated configuration of actions, laws, and ethics initiatives as complementary parts of the solution. There is no gain when a firm sorts its waste for recycling purposes and the city's waste management service fails to continue with the recycling process; part of the solution could be a local government incentive to encourage firms to opt for recycling. When a default institution or entity to guide and support sustainability policies is missing, in some cases the government is expected to take that role by means of official policies and by enforcing such policies; in other cases, the role will be assumed by a university or a firm, possibly a non-governmental organization (NGO) or a hybrid organism, and in the end, those institutions can be part of a complementary solution. There is a harsh reality: in some cases, people would prefer to keep their sources of employment despite pollution. For instance, communities around a firm that at the same time provides employment and generates pollution, such as the carbon industry, would probably prefer to deal with a polluted environment than losing their source of employment.

Clearly, this paper is not an attempt to solve the entire problem of sustainability. After all, a firm is just one entity among many entities in society, an important one, but only a part. The act of expanding the boundaries of the firm acknowledges the fact that said firm is part of the problem, but at the same time, by changing its way of seeing, the firm assumesits responsibility as part of the solution. Open boundaries may be a source of competitiveness. They are only one of the building blocks of the solution of a complex problem, which requires the combined actions of several agents and institutions, as well as sound policies, if the challenge of becoming a 
sustainable firm is to be tackled.

\section{Scope for Further Research}

Sustainability poses a number of exciting challenges and opportunities from both the practical and the theoretical points of view. Theoretically, a firm presents the challenge of having different levels of analysis: profit as a goal-seeking entity and integration with different research agendas. Finding a common ground among different researchorientations represents a pressing issue. From a firm's perspective, shaped by the way in which itsgoals are set, there are also restrictions and interactions associated with its environment, including legislation and the conditions of their resources, suppliers, and consumers.

Legislation itself presents the challenge of being flexible enough without compromising the environment and keeping the viability of the economic performance of local firms, while there is a strong consensus about the impact of the firm's products and activity. Trump's recent policy on carbon represents a regression; turning it overand presenting the case in a more compelling way is of utmost importance.

\section{Conclusions}

This paper is about sustainability, and the definition of responsibilities and boundaries of the firm, probably one of the most relevant issues in the current research and applied research sectors, and we recognize the lack of a single answer to this complex endeavor. This work asks for a holistic view in which there is not only one possible answer to the challenge of sustainability because the existence of substitutes is recognized, a complementary view than could enrich and help to find a proper response. The firm's view has been evolving from an economic point of view to a more open and comprehensive approach. As the interaction of the firm with its environment is noticed and its impact realized, the possibility of a sustainable environment becomes more viable.

Redefining the firm's boundaries is a first step, which acknowledges the firm's impact on the environment. Making external variables part of the firm's decision-making processes may allow for a higher degree of responsibility toward external challenges and opportunities. Also, legislation should foster innovation to improve sustainable performance and to help to differentiate between green firms and non-green firms. New technologies and new knowledge may facilitate the advancement of production, distribution, and consumption conditions aimed at reducing the negative impact of firms' activities. Finally, there is an increased awareness of responsibility among the business community towards a more sustainable society (Schmidheiny, 1992).

Inputs from sustainable sources are generally more expensive; in this regard, incentives to substitute non-sustainable inputs for sustainable ones could be put in place to decrease input-related costs. Still, a firm's pursuit of higher profits should not be the only decision-making driver. Expanding the boundaries of the firm can be one option in redefining its main goal; the level of profit could be one among several variables to take into account in developing and implementing decisions. Attempts to answer the question of whether being green pays off are faced by contradictory evidence; this paper suggests an extension from the point of view of profit: opening the boundaries of the firm to its environment so that profit is not the only relevant variable to determine action, because there are other drivers such as sustainability, the firm's reputation, and ethics, among others that should also be considered. The underlying assumption is the failure of current pricing systems, which do not necessarily integrate all costs, particularly the impact and damage to the environment.

Moreover, given the many differences across firm resources and legislation frameworks, comparing profits between green and non-green firms could be misleading. We argue that such comparisons and parameters are not clear because the relations of the firm with its environment and the ecological impact of its activities have not been adequately considered. A firm can take advantage of a relaxed legislation and overexploit its surroundings. The definition of the boundaries of the firm might also delimit its response. A firm's boundaries do have an impact on decisions regarding the desired level of sustainability. In an extended view, the level of sustainability should consider the supply chain, the employees, and the stakeholders, as well as the role of the firm in its environment. If a firm generates negative externalities, its individuals and activities have an impact on the quality of life in the firm's region. Firms interact at different levels, from the microeconomic and even personal to the macroeconomic level (from a bottom-up view). From their middle position, firms can certainly constitute a level of analysis, from which the interactions between people and the environment can be viewed.

Again, market is about efficient location - regardless of the level of sustainability, this gap can be overcome with an adequate legislation. Self-regulation can be influenced by external regulations that can have an impact on the company'sinternal regulation, and by extension, the definition of its boundaries and responsibilities. An adequate law can change the behavior of a firm and foster the emergence of new entities to help firms become sustainable. 
From a broader perspective, firms are part of a larger entity, they are part of a society. If the goal of conducting business is, in part having viable conditions for both firms and society, an enhanced view of the firm should be part of business considerations. Fortunately, there has been an increase in the awareness of the impact of the firm's goals and its alignment to the environment, which in turn increases the chances of finding and eventually achieving a common global sustainability goal. Nevertheless, there is still a challenge in designing an entity that makes sense, enforces, and guides the different efforts toward a comprehensive solution.

Because be responsible with the environment is both science and commitment; the background proposal of this paper is to achieve a Pareto optimal state where a redefinition of the firm's boundaries incorporating its environment might deliver a better outcome for all the players. A continuum considering the firm and the environment altogether-after all, the optimization of a complete system might generate more value than the optimization of a subsystem, such as a firm - may help to promote a sustainable firm and deliver a sustainable environment to society.

\section{References}

Alchian, A., \& Demsetz, H. (1972). Production, Information Costs and Economic Organization. American Economic Review, 62, 777-795.

Alston, L. J., \& Gillespie, W. (1989). Resource coordination and transaction costs: a framework for analysing the firm/market boundary. Journal of Economic Behaviour and Organization, 11, 191-212. https://doi.org/10.1016/0167-2681(89)90013-9

Ashkenas, R., Ulrich, D., Jick, T., \& Kerr, S. (1995). The Boundaryless Organization, Breaking the Chains of Organizational Structure. San Francisco: Jossey-Bass.

Bain, J. (1968). Industrial Organization. New York: John Wiley and Sons.

Barney, J. B. (1991). Firm resources and sustained competitive advantage. Journal of Management, 17, 99-120. http://dx.doi.org/10.1111/j.1468-0335.1937.tb00002.x

Carrillo, J. C. (1993). Strategic networks: Creating the borderless organization. Oxford: Butterworth-Neinemann Ltd.

Checkland, P. (1999). Systems Thinking, systems practice. New York: Wiley.

Coase, R. (1937). The Nature of the Firm, 4 Economica, 386-405.

Demsetz, H. (1967). Toward a theory of property rights. The American Economic Review, 57, 347-359. http://dx.doi.org/10.1057/9780230523210_9

Elkington, J. (1997). Cannibals with forks-Triple bottom line of 21st century business. Stoney Creek, CT: New Society Publishers.

Goel, P. (2010). Triple bottom line reporting: An analytical approach for corporate sustainability. Journal of Finance, Accounting, and Management, 1(1), 27-42.

Granovetter, M. (1985). Economic action and social structure: The problem of embeddedness. American Journal of Sociology, 91, 481-510. http://dx.doi.org/10.1086/228311

Gulati, R. (2000). Network location and learning: The influence of network resources and firm capabilities on alliance formation. Strategic Management Journal, 20, 397-420. http://dx.doi.org/10.1002/(SICI)1097-0266(199905)20:5\%3C397::AID-SMJ35\%3E3.0.CO;2-K

Hardin, G. (1968). The tragedy of the commons. Science, 162, 1243-1248. http://dx.doi.org/10.1080/19390450903037302

Hawken, P., Lovins, A., \& Lovins, L. H. (1999). Natural Capitalism: Creating the Next Industrial Revolution. New York: Little, Brown, and Co.

Hirschhorn, L., \& Gilmore, T. (1992). The new boundaries of the "boundaryless" company. Harvard Business Review, 70(3), 104-115.

Holmberg, J., \& Karl-Henrik, R. (2000). Backcasting from non-overlapping sustainability principles-a framework for strategic planning. International Journal of Sustainable Development and World Ecology, 7, 291-308. https://doi.org/10.1080/13504500009470049

Jensen, M., \& Meckling, W. (1976). Theory of the Firm: Managerial Behaviour, Agency Costs and Ownership Structure. Journal Financial Economics, 305-360. http://dx.doi.org/10.1016/0304-405X(76)90026-X

Kogut, B. (2000). The network as knowledge: Generative rules and the emergence of structure. Strategic 
Management

Journal,

20 ,

405-425. http://dx.doi.org/10.1002/(SICI)1097-0266(200003)21:3\%3C405::AID-SMJ103\%3E3.0.CO;2-5

Labuschagne, C., Brent, A. C., \& Van Erck, R. P. G. (2005). Assessing the sustainability performances of industries. Journal of Cleaner Production, 13, 373-385. http://dx.doi.org/10.1016/j.jclepro.2003.10.007

MacMillan, K., \& Farmer, D. (1979). Redefining the Boundaries of the Firm. Journal of Industrial Economics, 27, 277-285. http://dx.doi.org/10.2307/2098322

McEvily, B., \& Zaheer, A. (1999). Bridging ties; A source of firm heterogeneity in competitive capabilities. Strategic Management Journal, 1133-1156. http://dx.doi.org/10.1002/(SICI)1097-0266(199912)20:12\%3C1133::AID-SMJ74\%3E3.0.CO;2-7

Newbert, S. L. (2007). Empirical research on the resource-based view of the firm: an assessment and suggestions for future research. Strategic Management Journal, 28, 121-146. http://dx.doi.org/10.1002/smj.573

Nonaka, I., \& Nishiguchi, T. (2001). Knowledge emergence: Social, Technical, and Evolutionary dimensions of knowledge creation. New York: Oxford University Press.

Olson, M. Jr. (1968). The logic of collective action: Public goods and the theory of groups. New York: Schocken Books.

Özcan, O., \& Reeves, K. A. Jr. (2013). The firm boundary decision for sustainability-focused companies. Technological Solutions for Modern Logistics and Supply Chain Management (pp. 263-283). IGI Global. https://doi.org/10.4018/978-1-4666-2773-4.ch017

Penrose, E. (1959). The theory of the growth of the firm. New York: Oxford University Press. http://dx.doi.org/10.1093/0198289774.001.0001

Peteraf, M., \& Barney, A. J. B. (2003). Unravelling the Resource-Based Tangle. Managerial and Decision Economics, 24, 309-323. https://doi.org/10.1002/mde.1126

Porter, M. E. (1980). Competitive strategy. New York: The Free Press. http://dx.doi.org/10.1108/eb025476

Porter, M. E. (1985). Competitive advantage. New York: Free Press.

Porter, M. E. (1991). Towards a dynamic theory of strategy. Strategic Management Journal, 12, 95-117. http://dx.doi.org/10.1002/smj.4250121008

Reinhardt, F. L. (1998). Bringing the environment down to earth. Harvard business review, 77(4), 149-157.

Romer, P. M. (1986). Increasing Returns and Long-Run Growth. Journal of Political Economy, 94(5), 1002-1037. https://doi.org/10.1086/261420

Romer, P. M. (1994). The Origins of Endogenous Growth, Journal of Economic Perspectives, 8(1), 3-22. http://dx.doi.org/10.1086/261420

Schiele, H. (2007). Supply-management maturity, cost savings and purchasing absorptive capacity: testing the procurement performance link. Journal of Purchasing \& Supply Management, 13(4), 274e293. https://doi.org/10.1016/j.pursup.2007.10.002

Schmidheiny, S., \& BCSD. (1992). Changing Course (p. xii). Cambridge, MA: MIT Press.

Scott, W. R. (1992). Organizations: Rational, natural and open systems. Englewood Cliffs, N.J.: Prentice Hall Inc.

Shrivastava, P. (1995). The Role of Corporations in achieving Ecological Sustainability. The Academy of Management Review, 20, 936-960.

Simon, H. (1962). The architecture of complexity. Proceedings of the American Philosophical Society, 26, 467-482. http://dx.doi.org/10.1007/978-3-642-27922-5_23

Sjåfjell, B. (2016). Regulating for Corporate Sustainability: Why the Public-Private Divide Misses the Point.

Sjåfjell, B., \& Taylor, M. B. (2015). Planetary Boundaries and Company Law: Towards a Regulatory Ecology of Corporate Sustainability.

Takeishi, A. (2001). Bridging inter- and intra-firm boundaries: Management of supplier involvement in automobile product development. Strategic Management Journal, 22, 403-433. http://dx.doi.org/10.1002/smj.164

Teece, D. (1993). The dynamics of industrial capitalism: Perspectives on Alfred Chandler's scale and scope. Journal of Economic Literature, 31, 199-225. 
Weick K. E. (1976). Educational Organizations as Loosely Coupled Systems. Administrative Science Quarterly, 21, 1-19. http://dx.doi.org/10.2307/2391875

Williamson, O. E. (1975). MMarkets and Hierarchies: Analysis and Antitrust Implications. New York: Free Press.

\section{Copyrights}

Copyright for this article is retained by the author(s), with first publication rights granted to the journal.

This is an open-access article distributed under the terms and conditions of the Creative Commons Attribution license (http://creativecommons.org/licenses/by/4.0/). 